\title{
FMEA AKO SÚČASŤ PLÁNOVANIA KVALITY V POŠTOVÝCH PROCESOCH
}

\author{
Lucia Madleňáková*, Radovan Madleňák ${ }^{* *}$
}

\begin{abstract}
The paper is devoted to the themes and procedures concerning processing of express shipments inside postal company. The target of the paper is to find and identify possible process mistakes and errors, find solutions. For that purpose, Failure mode and Effect analysis method has been used. At the end of the paper several proposals for optimization of process in FMEA sheets can be found.
\end{abstract}

Keywords: process, FMEA Method, Quality planning, FMEA worksheet, Risk Number.

\section{1 Úvod do problematiky}

Rastúci význam plánovania kvality súvisí $\mathrm{s}$ dvoma hlavnými trendmi $\mathrm{v}$ oblasti manažmentu kvality (NENADÁL, a iní, 1998). Prvý trend je charakterizovaný ako posun od stratégie detekcie k stratégii prevencie. Druhý vývojový trend je súčinný s prvým a je daný ako posun starostlivosti o kvalitu z fázy výroby do fázy návrhu. Využitím vhodných metód už vo fáze návrhu a projektovania možno predchádzat' potenciálnym problémom ako vo fáze výroby tak i vo fáze spotreby (PLURA, 2001).

Plánovanie kvality je možné definovat' ako proces vymedzenia ciel'ov a spôsob ich dosahovania (PLURA, 2001). Predstavuje celý rad aktivít vo fázach návrhu a vývoja produktu, ktorých výsledkom je finálna kvalita produktu alebo služby. Empiricky je dokázané, že fázy predchádzajúce výrobe alebo poskytovaniu služby sa podiel'ajú na výslednej kvalite až v $80 \%$ to znamená, že $80 \%$ nezhôd produktu vzniká v predvýrobnej etape výrobného procesu. Ekonomický efekt plánovania je teda zrejmý, pretože odstránením nezhôd pred samotnou realizáciou produktu dochádza $\mathrm{k}$ eliminácii nákladov, ktoré by vznikli v prípade odstraňovania nezhôd vo fáze realizácie produktu alebo u zákazníka (PLURA, 2001). Príklady z praxe ukazujú, že výdavky spojené s odstránením nezhôd vo fáze návrhu, môžu byt' desat'krát nižšie než výdavky spojené s odstránením nezhody zistenej vo fáze výroby, stokrát nižšie než výdavky na odstránenie nezhôd či chýb zistených pred expedíciou a tisíckrát nižšie než výdavky na odstránenie nezhôd, ktoré sa dostanú až k zákazníkovi.

\section{Analýza súčasného stavu}

Plánovanie kvality nachádza svoje miesto aj v prostredí služieb, ktoré sú obvykle popísané prostredníctvom procesov dekomponovaných na subprocesy. Aj ked' je riešenie otázok kvality služieb často náročnejším procesom ako to býva pri hmotných produktoch,

\footnotetext{
*doc. Ing. Lucia Madleňáková, PhD., Katedra spojov, FPEDAS, Žilinská univerzita v Žiline, Univerzitná 1, 010 26 Žilina, Lucia.Madlenakova@ @pedas.uniza.sk

** doc. Ing. Radovan, Madleňák, PhD., Katedra spojov, FPEDAS, Žilinská univerzita v Žiline, Univerzitná 1, 01026 Žilina, Radovan.Madlenak@fpedas.uniza.sk
} 
metódy a prístupy uplatňované vo výrobnej sfére je možné aplikovat' aj v praxi služieb a nepochybne i v podmienkach poštových procesov. Pre uplatňovanie princípov a prístupov plánovania kvality poštových procesov existuje niekol'ko významných dôvodov:

- zásadným spôsobom rozhoduje o spokojnosti zákazníkov,

- predchádza sa vzniku nezhôd pri poskytovaní služby,

- v fáze návrhu alebo vývoja novej služby/procesu, pri ich inovácií vzniká najviac chýb,

- odstraňovanie chýb $\mathrm{v}$ priebehu plánovania kvality služby, si vyžaduje len zlomok nákladov potrebných k odstraňovaniu nezhôd, než v priebehu realizácie a spotreby služby,

- uplatňovaním metód a postupov plánovania kvality poštový podnik preukazuje, že využíva všetky prostriedky k prevencii nezhôd a dosiahnutiu spokojnosti zákazníkov a tak zvyšuje dôveru zákazníkov,

- správna realizácia plánovania kvality je dôležitým atribútom konkurencieschopnosti poštového podniku.

Plánovanie kvality je možné chápat' aj ako projektovanie budúcnosti, prostredníctvom ktorého sa určujú ciele či už celého podniku alebo vybranej organizačnej jednotky a stanovujú sa cesty, ako tieto ciele v stanovenom čase a na požadovanej úrovni dosiahnut'. Plán je možné považovat' za efektívny vtedy, ak sa dosiahnu vytýčené ciele pri vynaložení primeraných nákladov za predpokladu, že náklady nie sú vyjadrené len v časových a peňažných jednotkách, ale aj mierou uspokojenia jednotlivcov či pracovných skupín (MATEIDES, a iní, 2006). Z vývojom doby a nástrojov plánovania kvality vznikali aj postupy plánovania kvality, ktoré sú premietnuté napr. v súboroch noriem ISO 9000, štandardov či metód napr. (SALAVA, ŠVADLENKA, 2009):

- PPAP (Proces schval'ovania dielov $\mathrm{k}$ výrobe),

- APQP (Zdokonalené plánovanie kvality výrobku a kontrolný plán),

- FMEA (Analýza možností vzniku nezhôd a ich následkov),

- MSA (Analýza systému merania),

- SPC (Štatistická regulácia a hodnotenie spôsobilosti procesov)

- QFD Rozvoj funkcií kvality - nástroj transformáciu požiadaviek zákazníka do technických parametrov výrobku/služby.

Aj v podmienkach poštových služieb sú dnes už často uplatňované rôzne nástroje súvisiace $\mathrm{s}$ monitorovaním procesov a to nielen na úrovni procesného riadenia poštového podniku, ale predovšetkým v oblasti samotných technologických procesov. Dekompozícia procesov a ich mapovanie prostredníctvom optimalizačných či projekčných metód prinášajú v praxi pozitívne výsledky vzhl'adom na elimináciu miest potenciálneho i reálneho vzniku porúch či chýb.

\section{Ciel’ a metodika práce}

Základná metodika vyplýva z charakteru analýzy a diagnostiky vybraného objektu skúmania, ktorým je technologický proces spracovania expresných zásielok v triediacom stredisku pri exporte v podmienkach vybraného poštového podniku. Ciel'om bude diagnostika subprocesu „Debrief”, pre jej potreby bola zvolená metóda FMEA, ktorá je jednou zo základných metód využívaných v plánovaní kvality. Praktické skúsenosti naznačujú jej vhodné použitie najmä vo fáze návrhu, vývoja, inovácí́ služby či jej procesov, ale aj vo fáze následnej kontroly. Metóda FMEA je tímovou analýzou možnosti vzniku porúch a chýb posudzovaného produktu, služby či procesu. Ciel'om je ohodnotenie ich rizík v návrhu a realizácii opatrení vedúcich k zlepšeniu kvality návrhu (ČOREJOVÁ, ROSTÁŠOVÁ, 1999). Zmysel metodiky FMEA spočíva v špecifikácii všetkých možných chýb vzhl'adom k 
- Významu chyby

- Pravdepodobnosti vzniku chyby

- Odhaleniu chyby

Aplikácia metódy FMEA pozostáva z dvoch základných fáz:

1.fáza identifikácie, kedy sa experti sústred’ujú na identifikáciu:

- všetkých potenciálnych chýb, ktoré môžu vzniknút' $\mathrm{v}$ bežných i extrémnych prevádzkových podmienkach bez ohl'adu na ich záväznost' alebo pravdepodobnost' vzniku,

- všetkých možných následkov chýb,

- všetkých možných príčin vzniku danej chyby, pričom jedna chyba môže mat' viacero následkov a podobne jeden následok môže mat' viacero príčin,

2. numerická fáza, ktorá sa sústred’uje na výpočet miery rizika vo forme rizikového čísla (RPN), ktorá môže vzniknút' v prípade každej možnej príčiny chyby. Obvykle sa miera rizika počíta podl'a vzt'ahu:

\section{$\mathbf{R P N}=\mathbf{P} \times \mathbf{E} \times \mathbf{N}$}

kde:

- $\mathbf{P}$ - pravdepodobnost' výskytu poruchy,

- $\mathbf{E}$ - hodnotenie následkov poruchy/význam chyby,

- $\quad \mathbf{N}$ - pravdepodobnost', že porucha bude identifikovaná a nebude môct' pôsobit'.

Pri metóde FMEA sa odporúča využívat' štandardné pre zaznamenávanie analyzovaných údajov (pozri tab. 1). Hodnoty jednotlivých parametrov tvoriacich rizikové číslo volia experti na základe stupníc, ktoré sú zostavené l'ubovol’ne a pre každú konkrétnu situáciu môžu byt' vhodne modifikované. Štandardne sa používa stupnice s rozsahom 1 až 10 , pričom najlepšiemu hodnoteniu zodpovedá hodnota 1. Vypočítané hodnoty RPN umožňujú porovnanie jednotlivých chýb z hl'adiska ich príčin a následkov podl'a jednotného meradla. Hodnota RPN je určujúca pre riešenie rizikových oblastí/procesov/činností a výber a návrh nápravných opatrení či preventívnych opatrení, ktoré sú cielene zamerané na zamedzenie výskytu potenciálnych chýb. Po realizácií nápravných a preventívnych opatrení experti opät' posúdia hodnoty parametrov P,E,N a vypočítajú sa nové hodnoty RPN. Týmto spôsobom sa môže postupovat' $\mathrm{v}$ niekol'kých kolách, kým sa nedosiahne optimálna hodnota rizikového čísla. V súvislosti s hodnotou RPN je dôležité venovat' osobitnú pozornost' hodnote „význam chyby“. Môže totiž nastat' situácia, že hodnota RPN bude síce nízka, nakol'ko hodnoty $\mathrm{P}$ a $\mathrm{N}$ sú rovné jednej, len hodnota $\mathrm{E}$ je vysoká. Týka sa to najmä vel'mi závažných až krízových udalostí, ktoré sú obvykle vel'mi málo pravdepodobné. V súvislosti so širokým spektrom aplikácii metódy FMEA v rôznych typoch systémov a oblastí, existuje množstvo variantov metódy FMEA (STRENITZEROVÁ, 2014).

\section{Výhody FMEA v poštových procesoch}

- Predstavuje systémový prístup k prevencii nekvality.

- Znižuje straty vyvolané nízkou kvalitou poštového systému.

- Skracuje dobu riešení vývojových prác pri projektovaní nových služieb, procesov či ich inováciách.

- Optimalizuje návrhy a vedie $\mathrm{k}$ zníženiu počtu zmien vo fáze realizácie - umožňuje robit' veci správne na prvýkrát. Umožňuje ohodnotit' riziko vzniku možných chýb a na jeho základe stanovit' priority, opatrenia, vedúce k zlepšeniu kvality návrhu.

- Podporuje účelné využívanie zdrojov.

- Vytvára cennú informačnú databázu o systéme, využitel'nosti pre podobné systémy.

- Poskytuje podklady pre spracovanie alebo zlepšenie plánu kvality.

- Je dôležitou súčast’ou kontrolného systému v oblasti tvorby návrhu.

- Zlepšuje značku - meno a konkurencieschopnost' poštového podniku. 
- Pomáha zvýšit' spokojnost' zákazníka.

- Náklady vynaložené na jej vykonanie sú iba zlomkom nákladov, ktoré by mohli vzniknút' pri výskyte nezhôd.

\section{Výsledky a diskusia}

Na základe pozorovania a monitorovania procesu spracovania expresnej zásielky pri jej exporte vo vybranom triediacom centre boli identifikované riziká vzniku porúch a chýb, ktoré boli ohodnotené rizikovým číslom, hodnota ktorého naznačuje dôležitost' potreby ich eliminácie.

Základný proces spracovania expresnej zásielky pri exporte pozostáva $\mathrm{z}$ nasledujúcich krokov:

- „debrief” proces, resp. konfrontácia fyzického stavu zásielok so zoznamom vybratých zásielok určených na export, uzatváranie doručovacich aktivit, preberanie nedoručených zásielok a adekvátne pridel'ovanie skenov,

- príchod zásielok na operačné oddelenie a akceptácia nebezpečných zásielok na prepravu,

- zistenie reálnych rozmerov zásielok a ich hmotnosti (reweight) a činnost' triediacej linky,

- exportné colné odbavenie zásielok,

- detekčná kontrola a

- kontajnerizácia.

Tak ako bolo u vedené v cieli diagnostike bude podrobený čiastkový proces „Debrief““

Identifikácia rizík prvého kroku procesu spracovania expresnej zásielky pri exporte - Debrief proces spočíva predovšetkým v kontrole zásielok kompetentným zamestnancom vzhl'adom na kompletnost' a správnost' vyplnenia sprievodných a prevádzkových dokladov, označenie zásielok $\mathrm{V}$ súlade $\mathrm{s}$ pravidlami a podmienkami poštového podniku, pripravenost' nebezpečných tovarov musí byt' $\mathrm{v}$ súlade $\mathrm{s}$ medzinárodnými predpismi IATA, použitie náležitého označenia, a pod.

Identifikované slabé miesta procesu „debrief” - či už ako možnost' potenciálneho vzniku poruchy alebo aj porúch reálne vznikajúcich:

- použitý nesprávny jazyk (základný komunikačný jazyk medzinárodného poštového operátora je angličtina, je nevyhnutné bez ohl'adu na aktuálnu polohu riadit' sa podl'a jednotných pravidiel);

- nesprávne vyplnené prepravné a prevádzkové doklady, t. j. popis tovaru, poistenie, kontaktné údaje, adresa odosielatel'a a príjemcu, typ a kód produktu;

- nedostatočné alebo nesprávne označenie zásielky, t. j. chýbajúce označenie pre krehké zásielky, chýbajúce označenie pre sobotné doručenie, absencia alebo prekrytie orientačných šípok, štítok s výpočtom dobierky a podobne;

- znehodnotenie označenia nebezpečných tovarov, certifikát testovania vonkajšieho obalu, spotrebitel'ské označenie nebezpečnosti, ktoré môže byt' signálom rizika pre leteckú prepravu, zvláštne znaky ignorované kuriérom, ako napríklad vysoká alebo studená zásielka a pod.;

- poškodenie zásielky väčšieho alebo menšieho charakteru;

- nekompletná dokumentácia pri tovarových expresných zásielkach, t. j. chýbajúce dodacie listy, faktúry a kópia leteckého nákladového listu, kontrola zásielok a ich zaznamenávanie $\mathrm{v}$ príslušných dokladoch ( $\mathrm{v}$ prípade potreby dodatočné nahlasovanie dispečingu), apod. 
Tabul'ka 1 Formulár FMEA

\begin{tabular}{|c|c|c|c|c|c|c|c|c|c|c|c|c|}
\hline \multicolumn{4}{|c|}{ FMEA formulár hodnotenia procesu spracovania expresných zásielok pri exporte } & \multicolumn{5}{|c|}{ Fáza procesu: Debrief proces } & \multirow{2}{*}{\multicolumn{4}{|c|}{$\begin{array}{c}\text { Zlepšený stav po } \\
\text { realizovaní opatrení }\end{array}$}} \\
\hline \multirow[b]{2}{*}{$\begin{array}{l}\text { Pracovný } \\
\text { postup }\end{array}$} & \multirow[b]{2}{*}{ Potenciálne poruchy } & \multirow[b]{2}{*}{ Potenciálne dôsledky } & \multirow[b]{2}{*}{$\begin{array}{l}\text { Potenciálne príčiny } \\
\text { porúch }\end{array}$} & \multicolumn{4}{|c|}{ Ohodnotenie } & \multirow[b]{2}{*}{ Odporúčané opatrenia } & & & & \\
\hline & & & & 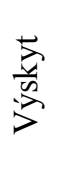 & 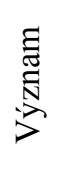 & $\begin{array}{l}\cdot \frac{0}{0} \\
\frac{0}{\pi} \\
\frac{\tilde{0}}{0}\end{array}$ & $\begin{array}{l}0 \\
0 \\
0 \\
0 \\
0 \\
01 \\
01\end{array}$ & & 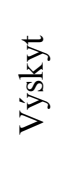 & 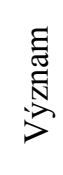 & $\begin{array}{l}\frac{0}{\pi} \\
\frac{0}{\pi} \\
\frac{\tilde{J}}{0} \\
0\end{array}$ & $\begin{array}{l}0 \\
0 \\
0 \\
0 \\
0 \\
0 \\
0\end{array}$ \\
\hline \multirow{3}{*}{$\begin{array}{c}\text { Debrief } \\
\text { proces }\end{array}$} & $\begin{array}{l}\text { Nesprávny jazyk použitý } \\
\text { na sprievodnej } \\
\text { dokumentácii a označení } \\
\text { zásielky }\end{array}$ & $\begin{array}{l}\text { Zdržanie zásielky } \\
\text { tranzitnej krajine, resp. v } \\
\text { krajine príjemcu, } \\
\text { problémy pri preclievaní, } \\
\text { neskoré doručenie, } \\
\text { nesprávna manipulácia } \\
\text { so zásielkou, } \\
\text { neakceptovanie zásielky } \\
\text { na prepravu zo strany } \\
\text { poštového podniku }\end{array}$ & \begin{tabular}{|c} 
Nedostatočná \\
kvalifikovanost' kuriérov, \\
slabý zaškolovací proces, \\
pri výbere uchádzačov je \\
dôležitým faktorom \\
výška nákladov
\end{tabular} & 6 & 6 & 2 & 72 & $\begin{array}{l}\text { Zvýšenie nárokov pri výbere } \\
\text { kandidátov na prácu kuriérov, } \\
\text { prispôsobenie už existujúceho } \\
\text { kurzu anglického jazyka } \\
\text { pracovnej dobe kuriérov }\end{array}$ & 3 & 3 & 2 & 18 \\
\hline & $\begin{array}{l}\text { Chýbajúce, resp. } \\
\text { nesprávne vyplnené } \\
\text { údaje na leteckom } \\
\text { nákladovom liste }\end{array}$ & $\begin{array}{l}\text { Nekorektný manifesting } \\
\text { zásielok, nesprávna } \\
\text { fakturácia klientovi }\end{array}$ & $\begin{array}{l}\text { Nesprávne údaje } \\
\text { predovšetkým pri E- } \\
\text { COM zásielkach, chyba } \\
\text { kuriéra v dôsledku } \\
\text { nedôslednosti }\end{array}$ & 6 & 7 & 3 & 126 & $\begin{array}{c}\text { Poučenie odosielatel'a, resp. } \\
\text { kuriérov }\end{array}$ & 3 & 3 & 3 & 27 \\
\hline & $\begin{array}{c}\text { Nedostatočné alebo } \\
\text { nesprávne označenie } \\
\text { zásielky }\end{array}$ & $\begin{array}{c}\text { Zlá manipulácia vedúca } \\
\text { až k poškodeniu zásielky, } \\
\text { neskoré doručenie, pri } \\
\text { chýbajúcej dobierke s } \\
\text { výpočtom sumy je nutné } \\
\text { opätovné kontaktovanie } \\
\text { príjemcu }\end{array}$ & $\begin{array}{l}\text { Chyba kuriéra v } \\
\text { dôsledku nedôslednosti, } \\
\text { resp. nedostatočné } \\
\text { informácie odosielatel'a o } \\
\text { obsahu zásielky }\end{array}$ & 7 & 8 & 4 & 224 & $\begin{array}{l}\text { Poučenie odosielatel'a a } \\
\text { kuriéra, budovanie povedomia } \\
\text { o prepravných podmienkach v } \\
\text { leteckej preprave, napr. } \\
\text { prezentáciou obsahujúcou } \\
\text { informácie čo sa deje so } \\
\text { zásielkou počas letu, prípadne } \\
\text { organizovanie návštev } \\
\text { zákazníkov na procese } \\
\text { spracovania }\end{array}$ & 6 & 6 & 2 & 72 \\
\hline
\end{tabular}


Pokračovanie tabul'ky 1

\begin{tabular}{|c|c|c|c|c|c|c|c|c|c|c|c|c|}
\hline \multicolumn{4}{|c|}{ FMEA Formulár hodnotenia procesu spracovania expresných zásielok pri vývoze } & \multicolumn{5}{|c|}{ Fáza procesu: Debrief proces } & \multirow{2}{*}{\multicolumn{4}{|c|}{$\begin{array}{c}\begin{array}{c}\text { Zlepšení stav po } \\
\text { realizovaní opatrení }\end{array} \\
\text { Ohodnotenie }\end{array}$}} \\
\hline \multirow[b]{2}{*}{$\begin{array}{l}\text { Pracovný } \\
\text { postup }\end{array}$} & \multirow[b]{2}{*}{ Potenciálne poruchy } & \multirow[b]{2}{*}{ Potenciálne dôsledky } & \multirow[b]{2}{*}{$\begin{array}{l}\text { Potenciálne príčiny } \\
\text { porúch }\end{array}$} & \multicolumn{4}{|c|}{ Ohodnotenie } & \multirow[b]{2}{*}{ Odporúčané opatrenia } & & & & \\
\hline & & & & $\frac{\sum_{i}}{\sqrt[n]{n}}$ & 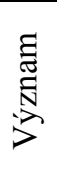 & $\frac{\mathscr{0}}{\frac{0}{\tilde{D}}}$ & 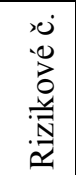 & & $\begin{array}{l}\frac{\hbar}{4} \\
i \\
j\end{array}$ & 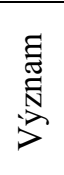 & 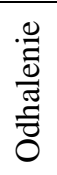 & 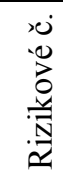 \\
\hline \multirow{3}{*}{$\begin{array}{l}\text { Bebrief } \\
\text { proces }\end{array}$} & $\begin{array}{l}\text { Nedostatočné alebo } \\
\text { nesprávne označenie } \\
\text { zásielky }\end{array}$ & $\begin{array}{l}\text { Zlá manipulácia vedúca } \\
\text { až k poškodeniu } \\
\text { zásielky, neskoré } \\
\text { doručenie, pri chýbajúcej } \\
\text { dobierke s výpočtom } \\
\text { sumy je nutné opätovné } \\
\text { kontaktovanie príjemcu }\end{array}$ & $\begin{array}{l}\text { Chyba kuriéra v } \\
\text { dôsledku nedôslednosti, } \\
\text { resp. nedostatočné } \\
\text { informovanie } \\
\text { odosielatel'a o obsahu } \\
\text { zásielky }\end{array}$ & 7 & 8 & 4 & 224 & $\begin{array}{l}\text { Poučenie odosielatel’a a } \\
\text { kuriéra, budovanie povedomia } \\
\text { o prepravných podmienkach v } \\
\text { leteckej preprave, napr. } \\
\text { prezentáciou obsahujúcou } \\
\text { informácie čo sa deje so } \\
\text { zásielkou počas letu, prípadne } \\
\text { organizovanie návštev } \\
\text { zákazníkov na procese } \\
\text { spracovania }\end{array}$ & 6 & 6 & 2 & 72 \\
\hline & $\begin{array}{c}\text { Nekompletná } \\
\text { dokumentácia a kvalita } \\
\text { vyplňovania bordereau } \\
\text { dokumentu }\end{array}$ & $\begin{array}{c}\text { Komplikácie pri } \\
\text { preclievaní, problémy s } \\
\text { colným úradom, } \\
\text { zadržané zásielky na čas } \\
\text { nevyhnutný na } \\
\text { odstránenie problému, } \\
\text { nízka kvalita skenovania } \\
\text { dokumentov o zásielkach }\end{array}$ & $\begin{array}{l}\text { Nedbanlivost' kuriéra, } \\
\text { zriedka chyba } \\
\text { odosielatel'a }\end{array}$ & 4 & 4 & 2 & 32 & $\begin{array}{l}\text { Nepretržitá kontrola podkladov } \\
\text { prevzatých od kuriérov a } \\
\text { okamžitá eskalácia problémov }\end{array}$ & 6 & 6 & 2 & 72 \\
\hline & $\begin{array}{l}\text { Podozrivé zásielky pre } \\
\text { leteckú prepravu, chybne } \\
\text { pripravené nebezpečné } \\
\text { tovary }\end{array}$ & $\begin{array}{l}\text { Zadržanie alebo zdržanie } \\
\text { zásielok, problémy } \\
\text { dopravcu s Dopravným } \\
\text { úradom odbor civilného } \\
\text { letectva, úsek } \\
\text { nebezpečné tovary, } \\
\text { potenciálne riziko } \\
\text { zranenia osôb a } \\
\text { poškodenia majetku } \\
\text { spoločnosti }\end{array}$ & $\begin{array}{l}\text { Neznalost' pravidiel } \\
\text { IATA zo strany } \\
\text { odosielatel'a, snaha } \\
\text { prepravit' zakázané alebo } \\
\text { regulované zásielky, } \\
\text { nedôslednost' kuriérov z } \\
\text { dôvodu značného } \\
\text { vyt'aženia }\end{array}$ & 7 & 9 & 5 & 315 & $\begin{array}{l}\text { Obozretnost' pri pridel’ovaní } \\
\text { zákazníckeho čísla na prepravu } \\
\text { nebezpečného tovaru, poučenie } \\
\text { zákazníkov o dôsledkoch ich } \\
\text { konania a informovanie } \\
\text { Dopravného úradu o každom } \\
\text { opakujúcom sa prípade }\end{array}$ & 4 & 9 & 4 & 144 \\
\hline
\end{tabular}




\section{Záver}

Aj ked' bola metóda FMEA pôvodne určená pre potreby preventívnej diagnostiky a teda v plánovaní kvality má jednoznačne svoje významné postavenie, je zrejmé, že jej použitie je významné aj z pohl'adu diagnostiky následnej, kedy umožňuje analýzu už vniknutých chýb. Použitie metódy je zrejmé predovšetkým tam, kde platia pravidlá kauzality, a teda aj v prostredí poštových technologických procesov.

Príspevok poukazuje na možnosti aplikácie metódy FMEA v prostredí poštových procesov, kde na základe pozorovania a štatistických záznamov boli vytypované miesta potenciálneho vzniku chýb, či miesta, kde chyby reálne vznikajú. Identifikované poruchy boli ohodnotené rizikovým číslom a na základe logických úsudkov a odvodzovania boli určené opatrenia k zefektívneniu procesu spracovania zásielok pri exporte.

\section{Literatúra}

[1] ČOREJOVÁ, T., ROSTÁŠOVÁ, M.: Diagnostický postup v manažérstve kvality v pošte /. - 1. vyd. - Žilina : Žilinská univerzita v EDIS, 1999. - 94 s. : obr. 30, tab. 11. - Lit. 76. ISBN 80-7100-619-X

[2] BLECHARZ, P.: Základy moderního řízení kvality. Vydavatel'stvo: Ekopress, 2011, ISBN: 9788086929750

[3] MADLEŇÁKOVÁ, M.: Procesné riadenie kvality v poštových službách. In: IPoCC International Postal and e-Communications Conference: sborník příspěvků mezinárodní konference IPoCC "Možnosti rozvoje poštovních služeb a elektronických komunikací" = proceedings of the IPoCC Conference "Possibilities of Postal Services and eCommunications Development" : Pardubice, September 13th-14th, 2012. - [Pardubice]: Institut Jana Pernera, 2012. - ISBN 978-80-86530-84-0. - CD-ROM, s. 144-149.

[4] MATEIDES, A. A KOLEKTÍV: Manažérstvo kvality (História, koncepty, metódy), Vydavatel'stvo: Epos, 2006, ISBN: 8080576564

[5] NENADAL, K.: Moderní systémy ř́zení jakosti. Quality Management.Praha: Management Press, 1998. ISBN 80-859-4363-8.

[6] PLURA, J.: Plánování a neustálé zlepšování jakosti. Vydavatel'stvo: Computer Press, 2001, ISBN: 8072265431

[7] STRENITZEROVÁ, M.: Uplatnenie metódy FMEA (Failure mode and effect analysis) pri diagnostikovaní kvality služieb. Diagnostika podniku, controlling a logistika [elektronický zdroj] : VII. medzinárodná vedecká konferencia : zborník prednášok a príspevkov : Žilina, 16.-17. apríl 2014. - Žilina: Žilinská univerzita, 2014. - ISBN 97880-554-0856-9. - CD-ROM, s. 300-307.

[8] ŠEVČÍK, P.: Spracovanie zásielok v podmienkach spoločnosti DHL Express (Slovakia), spol. s r. o. Diplomová práca, Katedra spojov, FPEDAS, ŽU v Žiline, 2014, školitel': Madleňáková Lucia

[9] SALAVA, D. - ŠVADLENKA, L. Quality Measurement in EU and Czech Postal Services Market. Perner's Contacts, 2009, vol. 4, no. 2, s. 108-113. ISSN: 1801-674X.

\section{Grantová podpora}

VEGA 1/0421/12 Modelovanie difúzie znalostí v podnikových hodnotových ret’azcoch 